\title{
Intercriteria analysis applied to university ranking system of Turkey
}

\section{Gökhan Çuvalcıoğlu', Veselina Bureva ${ }^{2}$ and Alžbeta Michalíková ${ }^{3,4}$}

\author{
${ }^{1}$ Department of Mathematics, University of Mersin \\ 33016 Yenişehir, Mersin, Turkey \\ e-mail: gcuvalcioglu@gmail.com \\ ${ }^{2}$ Intelligent Systems Laboratory, "Prof. Dr. Assen Zlatarov" University \\ 1 "Prof. Yakimov" Blvd., Burgas 8010, Bulgaria \\ e-mail: vbureva@btu.bg \\ ${ }^{3}$ Faculty of Natural Sciences, Matej Bel University \\ Tajovského 40, Banská Bystrica, Slovakia \\ e-mail: al zbeta.michalikova@umb.sk \\ ${ }^{4}$ Mathematical Institute, Slovak Academy of Sciences \\ Ďumbierska 1, Banská Bystrica, Slovakia
}

Received: 8 September 2019

Accepted: 24 October 2019

\begin{abstract}
In the current investigation, an application of the InterCriteria Analysis over a daaset of university rankings of Turkey is discused. InterCriteria Analysis is used to deremine possible dependencies or independencies between indicators used for universities evaluation. The comparison of the results is presented. The obtained results can be helpful for improvement of the universities estimation process using the appropriate parameters.
\end{abstract}

Keywords: InterCriteria Analysis, University rankings.

2010 Mathematics Subject Classification: 03E72.

\section{A brief introduction of InterCriteria Analysis}

InterCriteria Analysis (ICA) is a new method for decision making based on the theories of the intuitionistic fuzzy sets $[5,6,8]$ and index matrices [4]. Let us have an index matrix containing the criteria on the rows and objects on the columns. 


\begin{tabular}{c|ccccccc} 
& $O_{1}$ & $\cdots$ & $O_{i}$ & $\cdots$ & $O_{j}$ & $\cdots$ & $O_{n}$ \\
\hline$C_{1}$ & $a_{C_{1}, O_{1}}$ & $\cdots$ & $a_{C_{1}, O_{i}}$ & $\cdots$ & $a_{C_{1}, O_{1}}$ & $\cdots$ & $a_{C_{1}, O_{n}}$ \\
$\vdots$ & $\vdots$ & $\ddots$ & $\vdots$ & $\ddots$ & $\vdots$ & $\ddots$ & $\vdots$ \\
$C_{k}$ & $a_{C_{k}, O_{1}}$ & $\cdots$ & $a_{C_{k}, O_{i}}$ & $\cdots$ & $a_{C_{k}, O_{j}}$ & $\cdots$ & $a_{C_{k}, O_{n}}$ \\
$\vdots$ & $\vdots$ & $\ddots$ & $\vdots$ & $\ddots$ & $\vdots$ & $\ddots$ & $\vdots$ \\
$C_{l}$ & $a_{C_{l}, O_{1}}$ & $\cdots$ & $a_{C_{l}, O_{i}}$ & $\cdots$ & $a_{C_{l}, O_{j}}$ & $\cdots$ & $a_{C_{l}, O_{n}}$ \\
$\vdots$ & $\vdots$ & $\ddots$ & $\vdots$ & $\ddots$ & $\vdots$ & $\ddots$ & $\vdots$ \\
$C_{m}$ & $a_{C_{m}, O_{1}}$ & $\cdots$ & $a_{C_{m}, O_{i}}$ & $\cdots$ & $a_{C_{m}, O_{j}}$ & $\cdots$ & $a_{C_{m}, O_{n}}$
\end{tabular}

The intercriteria analysis makes comparison between every two criteria from adjacent rows and adjacent columns. There are counters that calculate the type of the relations between the criteria. If there are $<,<$ or $>,>$ the first counter increments, while if there are the relations $<,>$ or $>,<$ the value of the second counter increments. The procedure of ICA functioning is explained in [7]. The resulting index matrix has the following form:

\begin{tabular}{c|ccc} 
& $C_{1}$ & $\ldots$ & $C_{m}$ \\
\hline$C_{1}$ & $\left\langle\mu_{C_{1}, C_{1}}, v_{C_{1}, C_{1}}\right\rangle$ & $\ldots$ & $\left\langle\mu_{C_{1}, C m}, v_{C_{1}, C_{m}}\right\rangle$ \\
$\ldots$ & $\ldots$ & $\ldots$ & $\ldots$ \\
$C_{m}$ & $\left\langle\mu_{C_{m}, C_{1}}, v_{C m, C_{1}}\right\rangle$ & $\ldots$ & $\left\langle\mu_{C_{m}, C_{m}}, v_{C m, C m}\right\rangle$
\end{tabular}

The situation with the relations of type $=,=$ is investigated in [23] and different scenarios and algorithms for calculation are proposed.

The method is extended in several research works. Intercriteria analysis over intuitionistic fuzzy data is presented in [15]. ICA with triples is proposed in [10]. A version of the method using a special type of intuitionistic fuzzy implications is investigated in [3]. InterCriteria Analysis with interval-valued intuitionistic fuzzy evaluations is proposed in [2]. Threedimensional version of ICA is presented in [33].

InterCriteria analysis is successfully applied in different science fields. With respect to university rankings, there are similar steps of research conducted for the following countries: Bulgaria [16], Poland [18], Slovakia [14], United Kingdom [28], Australia [30], and India [20]. In the area of healthcare and medicine, there are applications of ICA from the recent years $[1,13$, 19, 27, 31, 32, 36]. The topic of ecology is discussed in [29]. Applications of the ICA over data of global competitiveness reports of the World Economic Forum are implemented in $[9,11,12]$. The ICA applications in the area of neural networks and genetic algorithms are presented in [21, 22, 24-26].

\section{Intercriteria analysis applied to the university rankings of Turkey}

The university rankings of Turkey are presented by URAP-University Ranking by Academic Performance which are established at the Informatics Institute of Middle East Technical University in 2009. The aim is to provide a ranking system for the ranking system for the world universities based on academic performance indicators that reflect the quality and the quantity of 
their scholarly publications [34, 35]. The University Ranking by Academic Performance evaluates 157 universities according to 5 indicators. The indicators are the following: paper score, total citation score, total scientific document score, number of graduated doctoral students, scientist/student score. The methodology of the indicators selection for the university rankings is described in $[34,35]$. The dependencies between the indicators are presented in the Figure 1 after ICA application over input data. The investigation is performed using the ICrAData Software [17].

\begin{tabular}{|c|c|c|c|c|c|}
\hline $\boldsymbol{\mu}$ & paper score & $\begin{array}{c}\text { total citation } \\
\text { score }\end{array}$ & $\begin{array}{c}\text { total scientific } \\
\text { document score }\end{array}$ & $\begin{array}{c}\text { number of } \\
\text { graduated doctoral } \\
\text { students }\end{array}$ & $\begin{array}{c}\text { scientist/ } \\
\text { student score }\end{array}$ \\
\hline paper score & $\langle\mathbf{1 . 0 0 , 0 . 0 0}\rangle$ & $\langle 0.87,0.13\rangle$ & $\langle 0.90,0.10\rangle$ & $\langle 0.73,0.25\rangle$ & $\langle 0.57,0.43\rangle$ \\
\hline total citation score & $\langle 0.87,0.13\rangle$ & $\langle\mathbf{1 . 0 0 , 0 . 0 0}\rangle$ & $\langle 0.89,0.11\rangle$ & $\langle 0.72,0.26\rangle$ & $\langle 0.53,0.47\rangle$ \\
\hline $\begin{array}{c}\text { total scientific } \\
\text { document score }\end{array}$ & $\langle 0.90,0.10\rangle$ & $\langle 0.89,0.11\rangle$ & $\langle\mathbf{1 . 0 0 , 0 . 0 0}\rangle$ & $\langle 0.76,0.22\rangle$ & $\langle 0.56,0.44\rangle$ \\
\hline $\begin{array}{c}\text { number of } \\
\text { graduated } \\
\text { doctoral students }\end{array}$ & $\langle 0.73,0.25\rangle$ & $\langle 0.72,0.26\rangle$ & $\langle 0.72,0.26\rangle$ & $\langle\mathbf{1 . 0 0 , 0 . 0 0}$ & $\langle 0.48,0.50\rangle$ \\
\hline $\begin{array}{c}\text { scientist/student } \\
\text { score }\end{array}$ & $\langle 0.57,0.43\rangle$ & $\langle 0.53,0.47\rangle$ & $\langle 0.56,0.44\rangle$ & $\langle 0.48,0.50\rangle$ & $\langle\mathbf{1 . 0 0 , 0 . 0 0}\rangle$ \\
\hline
\end{tabular}

Figure 1. Results of ICA application over input data for criteria relationships investigation

The results are visualized in the intuitionistic fuzzy triangle (Figure 2). The green points are the data (criteria) that have dependencies. The pink points present the independent indicators.

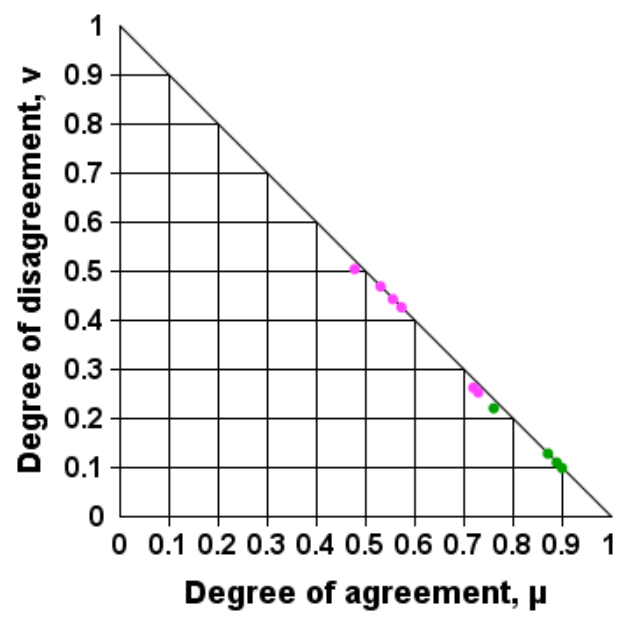

Figure 2. Results of ICA presented on the IF-triangle

The relationships between the indicators are determined using the intuitionistic fuzzy pairs from ICA application. The results are presented in the Figure 3. There are three pairs of indicators in strong dissonance, one pair of indicators in dissonance, two pairs of indicators in weak dissonance, one pair of criteria in weak positive consonance and 3 pairs of indicators in positive consonance. 


\begin{tabular}{|c|c|l|}
\hline Type of consonance & $\begin{array}{c}\text { Number } \\
\text { of pairs }\end{array}$ & \multicolumn{1}{c|}{ Description } \\
\hline $\begin{array}{c}\text { Strong Dissonance } \\
{[0,43 ; 0,57)}\end{array}$ & 3 & $\begin{array}{l}\text { total citation score }- \text { scientist/student score, } \\
\text { total scientific document score }- \text { scientist/student score, } \\
\text { number of graduated doctoral students - scientist/student score }\end{array}$ \\
\hline $\begin{array}{c}\text { Dissonance } \\
{[0,57 ; 0,67)}\end{array}$ & 1 & paper score - scientist/student score \\
\hline $\begin{array}{c}\text { Weak Dissonance } \\
{[0,67 ; 0,75)}\end{array}$ & 2 & $\begin{array}{l}\text { paper score }- \text { number of graduated doctoral students, } \\
\text { total citation score }- \text { number of graduated doctoral students }\end{array}$ \\
\hline $\begin{array}{c}\text { Weak Positive } \\
\text { Consonance } \\
{[0,75 ; 0,85)}\end{array}$ & 1 & $\begin{array}{l}\text { total scientific document score - number of graduated doctoral } \\
\text { students }\end{array}$ \\
\hline $\begin{array}{c}\text { Positive Consonance } \\
{[0,85 ; 0,95)}\end{array}$ & 3 & $\begin{array}{l}\text { paper score }- \text { total citation score, } \\
\text { paper score }- \text { total scientific document score, } \\
\text { total citation score }- \text { total scientific document score }\end{array}$ \\
\hline
\end{tabular}

Figure 3. Pairs of indicators (2018-2019)

The results of application of the ICA to the data for ranking system of Turkey show dependencies between the pairs of indicators "paper score-total citation score", "paper score-total scientific document score", "total citation score - total scientific document score" and "total scientific document score - number of graduated doctoral students". Obviously, there are relationships between the paper score, total scientific document score and total citation score. The dependency between total scientific document score and the number of graduated doctoral students is weak but the relation is considered as expected.

\section{Comparison of the results with investigations for the previous and next years}

The ICA is applied to the data of university rankings for two years: 2017-2018 and 2019-2020. The aim is to compare the results against the one obtained in the previous section. The outputs will determine the constant or variable behavior of the selected indicators. The results for year 2019-2020 are presented in Figure 4. Obviously, in the second application, the pair of indicators "paper score - scientist/student score" is moved from dissonance to strong dissonance. This arrangement confirms the harder independency between these two indicators.

At the next step, ICA is applied over the data for university rankings of 2017-2018. The results are presented in Figure 5. The third application confirms again the constant behavior of the indicators. There are 4 pair of indicators with dependencies and 6 pairs of indicators that are independent. The pairs in positive and weak positive consonance are "paper score-total citation score", "paper score - total scientific document score", "total citation score - total scientific document score" and "total scientific document score - number of graduated doctoral students". The pairs in dissonance, weak dissonance or strong dissonance are: "total citation score scientist/student score", "total scientific document score - scientist/student score", "number of graduated doctoral students - scientist/student score", "paper score-scientist/student score". 


\begin{tabular}{|c|c|l|}
\hline Type of consonance & $\begin{array}{c}\text { Number } \\
\text { of pairs }\end{array}$ & \multicolumn{1}{c|}{ Description } \\
\hline $\begin{array}{c}\text { Strong Dissonance } \\
{[0,43 ; 0,57)}\end{array}$ & 4 & $\begin{array}{l}\text { paper score }- \text { scientist/student score, } \\
\text { total citation score }- \text { scientist/student score, } \\
\text { total scientific document score }- \text { scientist/student score, } \\
\text { number of graduated doctoral students - scientist/student score }\end{array}$ \\
\hline $\begin{array}{c}\text { Weak Dissonance } \\
{[0,67 ; 0,75)}\end{array}$ & 2 & $\begin{array}{l}\text { paper score }- \text { number of graduated doctoral students, } \\
\text { total citation score }- \text { number of graduated doctoral students }\end{array}$ \\
\hline $\begin{array}{c}\text { Weak Positive } \\
\text { Consonance } \\
{[0,75 ; 0,85)}\end{array}$ & 1 & $\begin{array}{l}\text { total scientific document score }- \text { number of graduated doctoral } \\
\text { students }\end{array}$ \\
\hline $\begin{array}{c}\text { Positive Consonance } \\
{[0,85 ; 0,95)}\end{array}$ & 3 & $\begin{array}{l}\text { paper score }- \text { total citation score, } \\
\text { paper score }- \text { total scientific document score, } \\
\text { total citation score }- \text { total scientific document score }\end{array}$ \\
\hline
\end{tabular}

Figure 4. Pairs of indicators (2019-2020)

\begin{tabular}{|c|c|l|}
\hline Type of consonance & $\begin{array}{c}\text { Number } \\
\text { of pairs }\end{array}$ & \multicolumn{1}{|c|}{ Description } \\
\hline $\begin{array}{c}\text { Strong Dissonance } \\
{[0,43 ; 0,57)}\end{array}$ & 3 & $\begin{array}{l}\text { total citation score }- \text { scientist/student score, } \\
\text { total scientific document score }- \text { scientist/student score, } \\
\text { number of graduated doctoral students }- \text { scientist/student score }\end{array}$ \\
\hline $\begin{array}{c}\text { Dissonance } \\
{[0,57 ; 0,67)}\end{array}$ & 1 & paper score - scientist/student score \\
\hline $\begin{array}{c}\text { Weak Dissonance } \\
{[0,67 ; 0,75)}\end{array}$ & 2 & $\begin{array}{l}\text { paper score }- \text { number of graduated doctoral students, } \\
\text { total citation score }- \text { number of graduated doctoral students }\end{array}$ \\
\hline $\begin{array}{c}\text { Weak Positive } \\
\text { Consonance } \\
{[0,75 ; 0,85)}\end{array}$ & 1 & $\begin{array}{l}\text { total scientific document score }- \text { number of graduated doctoral } \\
\text { students }\end{array}$ \\
\hline $\begin{array}{c}\text { Positive Consonance } \\
{[0,85 ; 0,95)}\end{array}$ & 3 & $\begin{array}{l}\text { paper score }- \text { total citation score, } \\
\text { paper score }- \text { total scientific document score, } \\
\text { total citation score }- \text { total scientific document score }\end{array}$ \\
\hline
\end{tabular}

Figure 5. Pairs of indicators (2017-2018)

\section{Conclusion}

In the current research the ICA method for discovering hidden patterns in data is applied to the university rankings of Turkey, extracted from University Ranking by Academic Performance website. The results are confirmed in the years. The current investigation will be extended by investigation of the universities relationships. 


\section{Acknowledgements}

The Bulgarian author is thankful for the support provided by the Bulgarian National Science Fund under Grant Ref. No. KP-06-N22/1/2018 "Theoretical research and applications of InterCriteria Analysis".

\section{References}

[1] Andreev, N., Sotirova, E., \& Ribagin, S. (2019). Intercriteria analysis of data from data from the centers for transfusion haematology in Bulgaria, Comptes Rendus de l'Academie Bulgare des Science, 72 (7), 982-990.

[2] Atanassov, K., Marinov, P., \& Atanassova, V. (2019). InterCriteria Analysis with IntervalValued Intuitionistic Fuzzy Evaluations. In: Cuzzocrea A., Greco S., Larsen H., Saccà D., Andreasen T., Christiansen H. (eds) Flexible Query Answering Systems. FQAS 2019. Lecture Notes in Computer Science, 11529, 329-338.

[3] Atanassov, K., Ribagin, S., Sotirova, E., Bureva, V., Atanassova, V., \& Angelova, N. (2017). Intercriteria analysis using special type of intuitionistic fuzzy implications, Notes on Intuitionistic Fuzzy Sets, 23 (5), 61-65.

[4] Atanassov, K. (2014). Index Matrices: Towards an Augmented Matrix Calculus. Springer, Cham.

[5] Atanassov, K. (2012). On Intuitionistic Fuzzy Sets Theory, Springer, Berlin.

[6] Atanassov, K., Atanassova, V., \& Gluhchev, G. (2015). InterCriteria Analysis: Ideas and problems, Notes on Intuitionistic Fuzzy Sets, 21 (1), 81-88.

[7] Atanassov, K., Mavrov, D., \& Atanassova, V. (2014). InterCriteria Decision Making: A New Approach for Multicriteria Decision Making, Based on Index Matrices and Intuitionistic Fuzzy Sets. Issues in Intuitionistic Fuzzy Sets and Generalized Nets, 11, $1-8$.

[8] Atanassov, K., Szmidt, E., \& Kacprzyk, J. (2013). On intuitionistic fuzzy pairs, Notes on Intuitionistic Fuzzy Sets, 19 (3), 1-13.

[9] Atanassova, V., Doukovska, L., \& Krawczak, M. (2018) Intercriteria analysis of countries in transition from factor-driven to efficiency-driven economy, Notes on Intuitionistic Fuzzy Sets, 24 (2), 84-96.

[10] Atanassova, V., Doukovska, L., Michalikova, A., \& Radeva, I. (2016). Intercriteria analysis: From pairs to triples, Notes on Intuitionistic Fuzzy Sets, 22 (5), 98-110.

[11] Atanassova, V., Doukovska, De Tre, G., \& Radeva, I. (2017). Intercriteria analysis and comparison of innovation-driven and efficiency-to-innovation driven economies in the European Union. Notes on Intuitionistic Fuzzy Sets, 23 (3), 54-68.

[12] Atanassova, V., Doukovska, L. Mavrov, D., \& Atanassov, K. (2014). InterCriteria Decision Making Approach to EU Member States Competitiveness Analysis: Temporal and 
Threshold Analysis., In P. Angelov et al. (eds), Intelligent Systems'2014, Advances in Intelligent Systems and Computing, 322, 95-106.

[13] Bureva, V., Atanassov, K., \& Andreev, N. (2019). Intercriteria Analysis applied to Healthcare Rankings, Annual of Assen Zlatarov University, Burgas, Bulgaria, XLVIII (1), (in press).

[14] Bureva, V., Michalíková, A., Sotirova, E., Popov, S., Riečan, B., \& Roeva, O. (2017). Application of the InterCriteria Analysis to the universities rankings system in the Slovak Republic, Notes on Intuitionistic Fuzzy Sets, 23 (2), 128-140.

[15] Bureva, V., Sotirova, E., Atanassova, V., Angelova, N., \& Atanassov, K. (2018). Intercriteria Analysis over Intuitionistic Fuzzy Data. In: Lirkov I., Margenov S. (eds) Large-Scale Scientific Computing. LSSC 2017. Lecture Notes in Computer Science, 10665, Springer, Cham, 333-340.

[16] Bureva, V., Sotirova, E., Sotirov, S., \& Mavrov, D. (2015). Application of the InterCriteria decision making method to Bulgarian universities ranking, Notes on Intuitionistic Fuzzy Sets, 21 (2), 111-117.

[17] Ikonomov, N., Vassilev, P., \& Roeva, O. (2018). ICrAData - Software for InterCriteria Analysis, Int. J. Bioautomation, 22 (1), 1-10.

[18] Krawczak, M., Bureva, V., Sotirova, E., \& Szmidt, E. (2016). Application of the InterCriteria Decision Making Method to Universities Ranking, In: Novel Developments in Uncertainty Representation and Processing, Vol. 401, Advances in Intelligent Systems and Computing, Springer, 365-372.

[19] Krumova, S., Todinova, S., Mavrov, D., Marinov, P., Atanassova, V., Atanassov, K. \& Taneva, S. (2017). Intercriteria analysis of calorimetric data of blood serum proteome. Biochimica et Biophysica Acta - General Subjects, 1861 (2), 409-417.

[20] Parvathi, R., Atanassova, V., Doukovska, L., Yuvapriya, C., \& Indhurekha, K. (2018). InterCriteria Analysis of rankings of Indian universities, Notes on Intuitionistic Fuzzy Sets 24 (1), 99-109.

[21] Pencheva, T., Angelova, M., Atanassova, V., \& Roeva, O. (2015). InterCriteria analysis of genetic algorithm parameters in parameter identification, Notes on Intuitionistic Fuzzy Sets, $21(2), 99-110$.

[22] Roeva, O., Vassilev, P., Fidanova, S., \& Paprzycki, M. (2016). InterCriteria Analysis of Genetic Algorithms Performance, Recent Advances in Computational Optimization, Studies in Computational Intelligence, Springer, Vol. 655, 235-260.

[23] Roeva, O., Vassilev, P., Angelova, M., Su, J., \& Pencheva, T. (2016). Comparison of Different Algorithms for InterCriteria Relations Calculation. Proc. of IEEE 8th International Conference on Intelligent Systems, 567-572.

[24] Sotirov, S., Atanassova, V., Sotirova, E., Doukovska, L., Bureva, V., Mavrov, D., \& Tomov, J. (2017). Application of the Intuitionistic Fuzzy InterCriteria Analysis Method with Triples to a Neural Network Preprocessing Procedure, Computational Intelligence and Neuroscience, 2017, Article ID 2157852. 
[25] Sotirov, S., Sotirova, E., Melin, P., Castilo, O., \& Atanassov, K. (2016). Modular Neural Network Preprocessing Procedure with Intuitionistic Fuzzy InterCriteria Analysis Method, In:- Flexible Query Answering Systems, Advances in Intelligent Systems and Computing, 400, 175-186.

[26] Sotirov, S., Atanassova, V., Sotirova, E., Bureva, V., \& Mavrov, D. (2015). Application of the Intuitionistic Fuzzy InterCriteria Analysis Method to a Neural Network Preprocessing Procedure. Proc. of 16th World Congress of the International Fuzzy Systems Association (IFSA), 9th Conference of the European Society for Fuzzy Logic and Technology (EUSFLAT), 30.06-03.07.2015, Gijon, Spain, 1559-1564.

[27] Sotirov, S., Vankova, D. Vasilev, V., \& Sotirova, E. (2019). Clustering of Intercriteria Analysis Data Using a Health-Related Quality of Life Data, Lecture Notes in Computer Science, 11529, FQAS 2019: Flexible Query Answering Systems, 242-249.

[28] Sotirova, E., Bureva, V., Chountas, P., \& Krawczak, M. (2016). An application of intercriteria decision making method to the rankings of universities in the United Kingdom, Notes on Intuitionistic Fuzzy Sets, 22 (3), 112-119.

[29] Sotirova, E., Bureva, V., Markovska, I., Sotirov, S., \& Vankova, D. (2017). Application of the InterCriteria Analysis Over Air Quality Data. In: Christiansen H., Jaudoin H., Chountas P., Andreasen T., Legind Larsen H. (eds) Flexible Query Answering Systems. FQAS 2017. Lecture Notes in Computer Science, 10333, 226-235.

[30] Sotirova, E., \& Shannon, A. (2015). Application of intercriteria analysis to the rankings of Australian universities, Notes on Intuitionistic Fuzzy Sets, 21 (4), 136-142.

[31] Sotirova, E., Petrova, Y., \& Bozov, H. (2019). InterCriteria Analysis of oncological data of the patients for the city of Burgas, Notes on Intuitionistic Fuzzy Sets, 25 (2), 96-103.

[32] Todinova, S., Mavrov, D., Krumova, S., Marinov, P., Atanassova, V., Atanassov, K., \& Taneva, S. G. (2016). Blood Plasma Thermograms Dataset Analysis by Means of InterCriteria and Correlation Analyses for the Case of Colorectal Cancer. Int. J. Bioautomation, 20 (1), 115-124.

[33] Traneva, V., Tranev, S., Szmidt, E. \& Atanassov, K. (2018). Three dimensional intercriteria analysis over intuitionistic fuzzy data. In: J. Kacprzyk et al. (eds.), Advances in Fuzzy Logic and Technology 2017, Advances in Intelligent Systems and Computing, Springer, Vol. 641, $442-449 /$

[34] University Ranking by Academic Performance, Available online: http://tr.urapcenter.org/2018/

[35] University Ranking by Academic Performance, Available online: https://www. urapcenter.org/

[36] Vankova, D., Sotirova, E., \& Bureva, V. (2015). An application of the InterCriteria Analysis approach to health-related quality of life, Notes on Intuitionistic Fuzzy Sets, 21 (5), $40-48$. 